- Tỷ lệ thiếu/hụt Vitamin D ở trẻ là 93,86\%, trong đó trẻ trai là $54,21 \%$ cao hơn trẻ gái là $45,79 \%$

- Tỷ lê trẻ thiếu/hụt Vitamin $D$ cao nhất là ở lứa tuổi từ 24- 60 tháng $(76,17 \%)$.

\section{Triệu chứng lâm sàng của bệnh còi xương ở đối tượng nghiên cứu}

Triệu chứng lẩm sàng:

- 123 trẻ có biểu hiện quây khóc $(53,95 \%)$, trẻ có dấu hiệu ngủ không yên giấc, giật mình là 124 trẻ $(54,39 \%)$, trẻ có dấu hiệu vã mồ hôi, rụng tóc là 124 trẻ $(54,39 \%)$.

- Trong 228 trẻ nghiên cứu của chúng tôi có 214 trẻ có biểu hiện thiếu/hụt Vitamin $D$ tuy nhiên $100 \%$ số trẻ này đều không có các biểu hiện muộn của còi xương thiếu Vitamin $D$ như mềm xương sọ, có bướu trán, biến dạng xương hàm, răng mọc lộn xộn... Chỉ có $14,9 \%$ trẻ có biểu hiện thóp rộng và bờ thóp mềm, có 25 trẻ có biểu hiện chân vòng kiềng chiếm tỷ lệ 10,9\%.

\section{TÀI LIỆ THAM KHẢO}

1. Vũ Thi Thu Hiên và công sư (2012), "Tỷ lê thiếu Vitamin $D$ và một số yếu tố liên quan ở trẻ em 1 đến 6 tháng tuổi tại Hà Nội", Tạp chí Dinh dưỡng và Thực phẩm. 8 (4), tr. 8 - 16.

2. Nguyễn Văn Sơn (2000), Nghiên cứu các yếu tố nguy cơ còi xương dinh dưỡng ở trẻ em dưới 3 tuổi tại một số vùng miền núi phía Bắc và hiệu quả điều trị bẳng vitamin $D$ liều thấp, Luận án tiến sĩ, Trường Đại học Y Hà Nội.

3. Arnaud Laillou et al (2013), "Hypovitaminosis D and Mild Hypocalcaemia Are Highly Prevalent among Young Vietnamese Children and Women and Related to Low Dietary Intake", PLOS ONE. 8(5): e63979. (doi:10.1371/journal.pone.0063979).

4. N. Binkley, R. Ramamurthy và D. Krueger (2012), "Low vitamin D status: definition, prevalence, consequences, and correction", Rheum Dis Clin North Am. 38(1), tr. 45-59.

5. Bener A; Al-Ali M and Hoffmann GF (2009), "Vitamin D deficiency in healthy children in a sunny country: associated factors", Int J Food Sci Nutr. 60 (5): 60-70( doi: 10.1080/09637480802400487).

6. M. Hewison (2012), "Vitamin D and the immune system: new perspectives on an old theme", Rheum Dis Clin North Am. 38(1), tr. 125-39.

7. M. Peterlik và các cộng sự. (2009), "Vitamin $D$ and calcium insufficiency-related chronic diseases: an emerging world-wide public health problem", Int J Environ Res Public Health. 6(10), tr. 2585-607.

8. Jonathan M, Mansbach và Adit A (2009), "Serum 25-Hydroxyvitamin D Levels Among US Children Aged 1 to 11 Years: Do Children Need More Vitamin D", Pediatrics. 124;1404-1410.

9. Strand MA et al (2007), "Diagnosis of rickets and reassessment of prevalence among rural children in northern China", Pediatr Int. 49 (2): 202- 209.

\title{
ĐÁNH GIÁ HIÊUU QUẢ ĐÎ̀U TRI BÊNH BẠCH CẦU CẤP DÒNG LYMPHO B Ở TRẺ EM CÓ ĐộT BIẾN CHUYỂN ĐOẠN t(1;19)
}

\section{TÓM TẮT}

Mục tiêu nghiên cứu: Đánh giá đặc điểm sinh hoc, hiệu quả điều trị lâu dài, thời gian sống còn và biến chứng điều trị bạch câu cấp lympho B (BCCLB) trẻ em có đột biển $t(1 ; 19)$ bằng phác đồ FRALLE 2000. Phương pháp nghiên cứu: Mô tả hàng loạt ca, hồi cứu. Đối tượng nghiên cứu: 38 bệnh nhẩn (BN) thỏa tiêu chuẩn chọn mẫu với tuổi trung vị là 5 tuổi, được điều trị bằng phác đồ FRALLE 2000 tại khoa Huyết học Trẻ em 1 và Huyết học trẻ em 2 - Bệnh viện Truyền máu Huyết Hơc từ 2010 - 2020. Kết quả: Đột biến sinh học phân tử khác kèm theo là khá phổ biến (39,5\%). Đa số không có kiểu hình miễn dịch bất thường (LAIPs) theo dõi tồn lưu tế bào ác tính (MRD)

\footnotetext{
*Đại Học Y Dược TP. HCM, Bệnh viện Truyền máu Huyêt họ TP. HCM

Chịu trách nhiệm chính: Đinh Gia Khánh

Email: gkhanh94@gmail.com

Ngày nhận bài: 2.6.2021

Ngày phản biện khoa học: 3.8.2021

Ngày duyệt bài: 10.8.2021
}

\section{Đinh Gia Khánh*, Huỳnh Nghĩa*}

(89,5\%). Toàn bộ BN đạt lui bệnh sau giai đoạn tấn công của phác đồ, chúng tôi ghi nhận thời gian sống toàn bộ (OS) và thời gian sống không sự kiện (EFS) sau 5 năm lần lượt là là $84,4 \%$ và $70,9 \%$. Tỉ lệ tái phát tích luỹ là $27,1 \%$. Không có sự khác biệt có ý nghĩa OS, EFS giữa nhóm $\mathrm{t}(1 ; 19)$ đởn độc và nhóm $\mathrm{t}(1 ; 19)$ kèm bất thường khác. MRD dương tính sau tấn công là yếu tố tiên lượng mạnh mẽ nhất, cho EFS khác biệt có ý nghĩa $(p<0,01)$. Biến chứng nổi bật là nhiễm trùng, gặp trong mọi giai đoạn của điều trị. Một trường hợp $(2,6 \%)$ tử vong trong điêuu trị do liệt ruột và sốc nhiếm trùng. Kết luân: MRD dương tính sau tấn công làm tăng nguy cơ tái phát bệnh. Tuy nhiên BCCLB ở trẻ em có $t(1 ; 19)$ đa số không có LAIPs để theo dõi MRD bằng kỹ thuật dòng chảy tế bào (Flow cytometry), công cư sinh học phân tử là trung tâm để theo dõi sau điều trị. Với phác đồ FRALLE 2000 được áp dụng tại bênh viện Truyền máu - Huyết học, hiệu quả điều trị khá tốt, tương đương với điêu trị BCCLB trẻ em nói chung. Cho thây chuyển đoạn $\mathrm{t}(1 ; 19)$ không phải là yếu tố tiên lượng xấu.

Tư khóa: Bach cầu cấp lympho, chuyển đoạn $\mathrm{t}(1 ; 19)$, tổ hợp gen E2A-PBX1 


\section{SUMMARY \\ EVALUATION OF THE EFFICIENCY OF T(1;19) MUTATION CHILDHOOD B - CELL ACUTE LYMPHOBLASTIC LEUKEMIA TREATMENT}

Objective: To evaluate of biologica characteristics, long-term outcome, survival time and complications of $\mathrm{t}(1 ; 19)$ mutation childhood B-cell acute lymphoblastic leukemia treatment by using FRALLE 2000 protocol. Methods: A retrospective case series study of 38 patients met sample's criterias with median age of 5 years old, treated with FRALLE 2000 protocol at Pediatric departments 1 and 2 - Blood Transfusion and Hematology hospital from 2010 to 2020. Results: Additional cytogenetic abnormalities were fairly common (39.5\%). $89.5 \%$ of cases did not have Leukemia-Associated-Immunophenotypes (LAIPs) to detect Minimal Residual Disease (MRD) by multiparameter flow cytometry. All patients achieved complete remission after induction therapy. Overall survival (OS) and the Event-free survival (EFS) after 5 years were $84.4 \%$ and $70.9 \%$. The cumulative incidence of relapse was $27.1 \%$. There was no significant difference in OS, EFS between $\mathrm{t}(1 ; 19)$ alone and $\mathrm{t}(1 ; 19)$ with other abnormalities group. Endinduction MRD was the most powerful prognostic factor, indicated that significant differences in EFS $(p<0,01)$. Infectious complications are prominent, encountered at all stages of treatment. TreatmentRelated Mortality was $2.6 \%$ (one case), due to paralytic ileus and septic shock. Conclusion: Endinduction MRD positive has increased the risk of relapse. However, the majority did not have LAIPs to monitor MRD by FC, so molecular biology method is the most important to measure MRD. With the FRALLE 2000 protocol applied at the Blood Transfusion and Hematology hospital, the treatment was quite effective, equivalent to result of the general treatment of childhood acute lymphoblastic leukemia. It has been shown that $t(1 ; 19)$ translocation is not an adverse prognostic factor.

Keyword: acute lymphoblastic leukemia, translocation $\mathrm{t}(1 ; 19)$, E2A/PBX1 fusion.

\section{I. ĐẶT VẤN ĐỀ}

Bạch cầu cấp lympho $B(B C C L B)$ là bệnh lý ác tính thường gặp nhất ở trẻ em. Nhìn chung đây là nhóm bệnh ung thư có khả năng điều trị khỏi bệnh và thời gian sống còn khá cao [1],[6]. Tuy nhiên, thời gian sống còn và tỉ lệ tái phát có sự khác biệt rất đáng kể giữa các nhóm nguy cơ [6]. Do đó chiến lược phân tầng là vô cùng quan trọng trong chọn lựa cường độ nhằm tối ưu hoá hiệu quả của phác đồ và cân bằng với độc tính của thuốc. Các yếu tố đã được chứng minh và hiện đang được ứng dụng trong lâm sàng bao gồm tuổi, số lượng bạch cầu lúc chẩn đoán, đột biến sinh học di truyền, sự nhạy cảm với corticoid, tồn lưu tế bào ác tính tối thiểu (MRD) sau điều trị,...

Trong đó, công cụ sinh học phân tử là một trong những yếu tố quan trọng nhất để tiên lượng và xếp nhóm phác đồ. Bên cạnh một số đột biến đã được chứng minh là tiên lượng tốt và nển được hoá trị liêu liều chuẩn, các đột biến tiên lượng xấu cần liều cao hoặc phối hợp tác nhân trúng đích thì chuyển đoạn $t(1 ; 19)$ lại có giá trị tiên lượng còn nhiều bàn cãi và thay đổi theo thời gian. Kết quả nghiên cứu về đối tượng này cũng chưa có kết quả đồng bộ, trước đây nó được xếp vào nhóm nguy cơ cao và khuyến khích điều trị cường độ mạnh, nhưng dần được loại khỏi phân loại và được đưa vào nhóm có nguy cơ trung bình.

Là một đột biến nhìn chung tương đối hiếm trong BCCLB ở trẻ em (Chiếm từ 4 - 6\%). Các dữ liêu nghiên cứu về $t(1 ; 19)$ có phần hạn chế, ở Việt Nam vẫn chưa có một một nghiển cứu cụ thể về đối tượng này. Chúng tôi tiến hành nghiên cứu này với trọng tâm nhằm đánh giá hiệu quả điều trị bệnh nhi BCCLB có $t(1 ; 19)$ đang được áp dụng phác đồ FRALLE 2000 tại Bệnh viện Truyền máu Huyết Học Tp. Hồ Chí Minh.

\section{II. ĐỐl TƯƠNNG VÀ PHƯƠNG PHÁP NGHIÊN CỨU}

Đối tượng nghiên cứu. 38 bệnh nhi được chẩn đoán BCCLB có đột biến $\mathrm{t}(1 ; 19)$ và tổ hợp gen E2A-PBX1 tại bệnh viện Truyên máu Huyết học từ năm 2010 đến tháng 6/2020.

Thiết kế nghiên cứu. Mô tả hàng loạt $\mathrm{ca}$, hồi cứu.

\section{Phương pháp nghiên cứu}

Tiêu chuẩn chon mấu. Tất cả các tiêu chuẩn sau: Tuổi < 16 tuổi; chẩn đoán xác định là bạch cầu cấp dòng lympho $B$ dựa trên lâm sàng, huyết - tuỷ đồ; Có đột biến $t(1 ; 19)$ trên Nhiểm sắc thể đồ và/hoặc trên FISH;

Tiêu chuấn loại trừ. Bệnh nhi có bất kỳ 1 tiêu chuẩn nào sau đây sẽ được loại khỏi nghiên cứu: Từng được hoá trị trước ngày đâuu nhập viện; Mắc bệnh lý ác tính khác đồng thời; Có đột biến di truyền bẩm sinh;

Phương pháp điêu trị. Toàn bộ sẽ được điều trị theo phác đồ FRALLE 2000 nhóm $B$ gồm các giai đoạn: Test corticoid, Tấn công, củng cố, tăng cường 1 , trung gian, tăng cường 2 và giai đoạn duy trì [3].

- Phác đồ phân nhóm B1 được áp dụng khi bệnh nhi nhạy cảm với corticoid vào N8 (Blast ngoại biên < 1000/uL) và nhạy cảm với hoá trị tấn công N21 (Blast tuỷ < 5\%).

- Kháng corticoid N8, kháng với hoá trị liệu vào N21 sẽ được điều trị theo phân nhóm B2. Bên cạnh đó, một số trường hợp nhiều yếu tố nguy cơ cao (tuổi >10, nhiều đột biến kèm theo, 
xâm lấn cơ quan ngoài tuỷ lúc chẩn đoán, hoặc nằm quá gần ở ranh giới kháng corticoid, kháng hoá trị liệu N21) cũng được quyết định phác đồ nhóm B2.

- Sau giai đoạn tấn công, đánh giá tuỷ đồ và MRD, phác đồ chỉ tiếp tục khi bệnh nhân đạt được lui bệnh về mặt tế bào trên tuỷ đồ (Blast < $5 \%$ ).

MRD được đánh giá bằng 2 phương pháp:

- Phương pháp Flow cytometry: Áp dụng khi bệnh nhân có kiểu hình LAIPs, định lượng được quần thể tế bào có kiểu hình bất thường.

- Phương pháp sinh học phân tử: Toàn bộ được khảo sát định tính bằng RT-PCR tổ hợp E2APBX1 (Độ nhạy khoảng 10-3). Kỹ thuật PCR định lượng (RQ-PCR) được áp dụng gần đây, cho phép xác định chính xác hơn về lượng tế bào tồn lưu.

Chúng tôi áp dụng khái niệm MRD âm tính khi:

- RT-PCR âm tính với tổ hợp E2A-PBX1 và

- Kết quả định lượng bằng RQ-PCR hoặc Flowcytometry $<10^{-4}$

Phương pháp thu thập và xử lý số liệu
Các thông tin được thu thập bao gồm thông tin hành chính, đặc điểm lâm sàng, sinh học, thông tin trong và sau quá trình điều trị. Dữ liệu được nhập, phân tích bằng Microsoft Excel 365 và phần mềm $\mathrm{R}$ 4.1.0.

\section{Biến số chính của nghiên cứu:}

- Thời gian sống toàn bộ (OS): Thời gian tính bằng năm, từ lúc bệnh nhân bắt đầu điều trị đến khi tử vong vì bất kỳ nguyên nhân nào, hay mất theo dõi hoặc kết thúc nghiên cứu.

- Thời gian sống không sự kiện (EFS): Thời gian tính bằng năm, từ lúc bênh nhân bắt đầu điều trị cho đến khi tái phát, độc tính nghiêm trọng hay biến chứng nghiêm trọng phải ngưng điều trị, tử vong do bất kỳ nguyên nhân nào, hay mất theo dõi hoặc kết thúc nghiên cứu.

\section{KẾT QUẢ NGHIÊN CỨU}

Đặc điểm chung. Từ tháng $1 / 2010$ đến 6/2020, 38 bệnh nhân thoả điều kiện chọn mấu. Có độ tuổi trung vị là 5 tuổi (Từ 1 - 16 tuổi). Tỉ lệ nam/nữ là $1,1 / 1$.

Bảng 4. Đặc điểm chung của nhóm nghiên cứu

\begin{tabular}{|c|c|c|c|}
\hline Đặc điếm & & Số lượng (n) & Tỉ lệ \\
\hline \multirow{2}{*}{ Tuổi } & 1 - dưới 10 tuối & 26 & $68,4 \%$ \\
\cline { 2 - 4 } & Trên 10 tuối & 12 & $31,6 \%$ \\
\hline \multirow{2}{*}{$\begin{array}{c}\text { Bất thường di truyền } \\
\text { học kèm theo }\end{array}$} & $\mathrm{t}(1 ; 19)$ đơn thuần & 23 & $60,5 \%$ \\
\hline \multirow{3}{*}{$\begin{array}{c}\text { Đặc điểm Nhiễm sắc } \\
\text { thể đồ }\end{array}$} & $\mathrm{t}(1 ; 19)$ kèm theo bất thường khác & 15 & $39,5 \%$ \\
\cline { 2 - 4 } & Chuyến đoạn t(1;19) cân bằng & 11 & $28,9 \%$ \\
\cline { 2 - 4 } & Chuyến đoạn t(1;19) không cân bằng & 16 & $42,1 \%$ \\
\cline { 2 - 4 } & Cấy không mọc NST & 1 & $2,6 \%$ \\
\hline \multirow{2}{*}{$\begin{array}{c}\text { FISH xác định } \\
\text { chuyển vị t(1;19) }\end{array}$} & NST bình thường & 10 & $26,3 \%$ \\
\hline \multirow{2}{*}{ RT-PCR (E2A-PBX1) } & Dương tính & 38 & $100 \%$ \\
\cline { 2 - 4 } & Amm tính & 0 & $0 \%$ \\
\cline { 2 - 4 } & Dương tính & 38 & $100 \%$ \\
\hline
\end{tabular}

Tôn lưu tế bào ác tính sau tấn công

Bằng phương pháp Flow cytometry, chỉ có $n=4(10,5 \%)$ có kiểu hình LAIPs để theo dõi MRD sau điều trị, và tất cả đều âm tính sau giai đoạn tấn công. Đối với phương pháp sinh học phân tử, chúng tôi ghi nhận $n=4(10,5 \%)$ có MRD dương tính sau tấn công (Hình 1)

MRD sau tấn công (Sinh học phân tử)

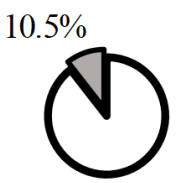

$89.5 \%$
口Âm tính

口Dương tính

\section{Hình 1. Tồn lưu tế bào ác tính sau tấn công}

Thời gian sống còn. Thời gian sống toàn bộ (OS) và sống không sự kiện (EFS). Với thời gian theo dõi trung vị là 4,5 năm. Chúng tôi ghi nhận OS-5 năm và EFS-5 năm của mẫu nghiên cứu lần lượt là 84,4\% (KTC 95\%: 72,7 - 98,1\%) và 70,9\% (KTC 95\%: 55,3 - 90,8\%) (Hình 2) 

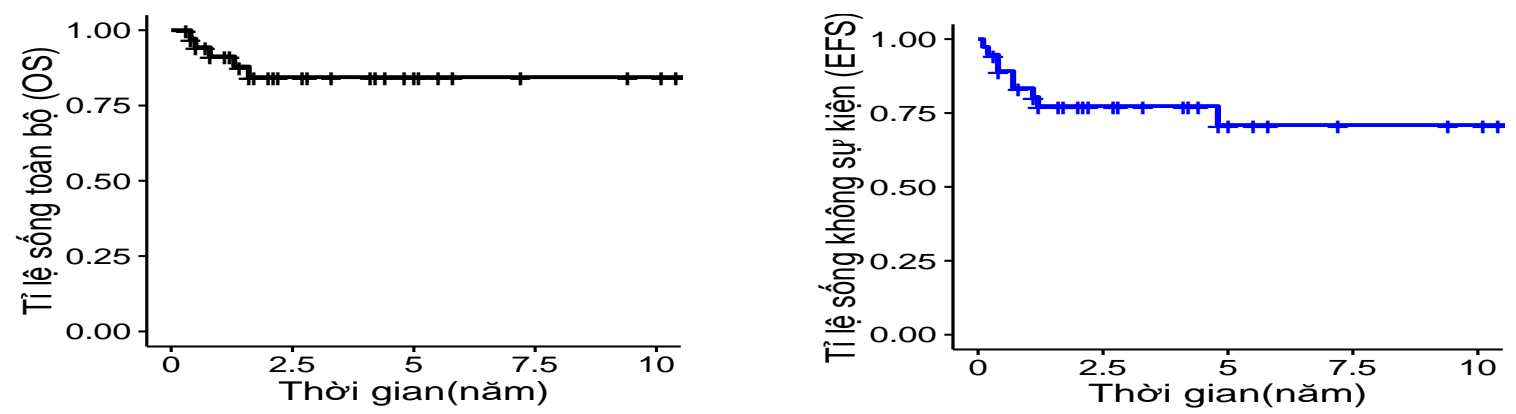

Hình 2. Kaplan-Meier biểu diễn thời gian sống toàn bộ (OS) và sống không sự kiện (EFS) của mẫu nghiên cứu.

Các yễu tố nguy cơ khác ảnh hưởng thời gian sống còn

\section{Bảng 5. Phân tích các yêu tố liền quan với thời gian sống còn}

\begin{tabular}{|c|c|c|c|c|c|}
\hline 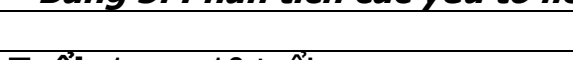 & n & OS-5y & log-rank $P$ & EFS-5y & log-rank P \\
\hline Tuối: $1-<10$ tuối & 26 & $82,8 \%$ & \multirow{2}{*}{0,6} & $76,3 \%$ & \multirow{2}{*}{0,9} \\
\hline$\geq 10$ tuối & 12 & $88,9 \%$ & & $53,3 \%$ & \\
\hline Giới: & 20 & $82,6 \%$ & \multirow{2}{*}{0,92} & $67,3 \%$ & \multirow{2}{*}{0,97} \\
\hline Nữ & 18 & $87,5 \%$ & & $75,6 \%$ & \\
\hline BC lúc chấn đoán: < $50 \mathrm{k} / \mathrm{uL}$ & 27 & $90,9 \%$ & 0,07 & $76,1 \%$ & \multirow[b]{2}{*}{0,18} \\
\hline$\geq 50 \mathrm{k} / \mathrm{uL}$ & 11 & $68,2 \%$ & & $62,3 \%$ & \\
\hline Nhạy corticoid N8: Nhạy & 29 & $84,3 \%$ & \multirow{2}{*}{0,87} & $67,5 \%$ & \multirow{2}{*}{0,39} \\
\hline Không nhạy & 9 & $85,7 \%$ & & $85,7 \%$ & \\
\hline Phác đồ điêu trị: FRALLE 2000 B1 & 19 & $88,0 \%$ & \multirow{2}{*}{0,52} & $67,7 \%$ & \multirow{2}{*}{0,99} \\
\hline FRALLE 2000 B2 & 19 & $79,8 \%$ & & $76,5 \%$ & \\
\hline
\end{tabular}

Ảnh hưởng của MRD lên thời gian sống còn. Nhóm MRD dương tính có 4 bệnh nhi, nhưng thời gian theo dõi dài nhất chỉ 0,8 năm. Phân tích sống còn cho thấy không có sự khác biệt giữa nhóm có MRD âm và dương về thời gian $\mathrm{OS}(\mathrm{p}=0,1)$, nhưng khác biệt có ý nghĩa về thời gian $\mathrm{EFS}$ $(p=0,005)$.

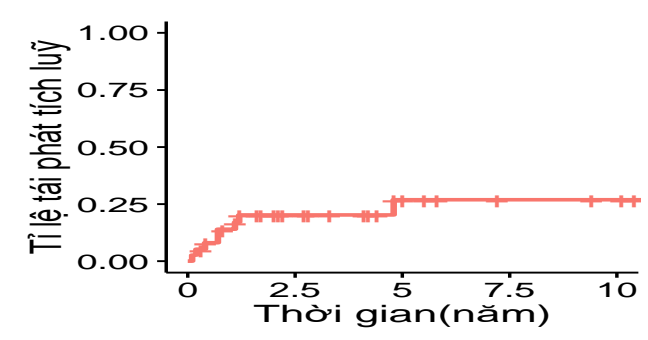

\section{Tỉ lệ Tái phát.}

\section{Hình 3. Ti lệ tái phát tích luỹ của mẫu nghiên cứu}

Tỉ lệ tái phát tích luỹ sau 10 năm ghi nhận là 27,1\% (Hình 3)

Tái phát chung là $n=8(21,1 \%)$, trong đó chủ yếu là tái phát tuỷ và thần kinh trung ương $\mathrm{n}$ $=4$ (chiếm $50 \%$ ). Tái phát thần kinh trung ương hoặc tái phát tuỷ đơn độc chiếm $n=2(25 \%)$. Hầu hết đều là tái phát rất sớm $n=7(87,5 \%)$ (Trong vòng 18 tháng sau khi có chẩn đoán ban đầu). Xuất hiện nhiều nhất ở giai đoạn duy trì $n$ $=3(37,5 \%)$. Yếu tố có liên quan chặt chẽ làm tăng nguy cơ tái phát là MRD dương tính sau tấn công $(p=0,0015)$ (Hình 3)

Độc tính và tai biến trong điêu trị. Tỉ lệ

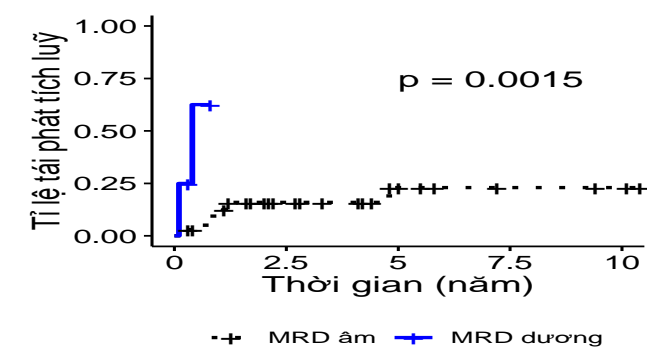

lui bệnh sau giai đoạn tấn công là $100 \%$. Biến chứng nhiếm trùng xuất hiện ở mọi giai đoạn của điều trị. Nhiều nhất ở giai đoạn tấn công, nổi bật là nhiễm trùng tiêu hoá $n=8(21,0 \%)$. Biến chứng nặng nề là nhiễm trùng huyết chiếm $\mathrm{n}=$ $7(18,42 \%)$; Các tác dụng ngoại ý khác là tăng transaminase gan, chủ yếu độ I-II, gặp ở hầu hết các giai đoạn. Trong các giai đoạn sử dụng L-asparaginase, các tác dụng phụ tăng Amylase, giảm Fibrinogen thường gặp thường mức độ nhẹ, nhưng nguyên nhân thường nhất khiến trì hoã̃n sử dụng thuốc. Một trường hợp $(2,6 \%)$ có biến chứng xơ tuỷ thứ phát sau điều trị, dẫn đến 
nhiễm trùng huyết, nhiễm nấm huyết rất nặng, viêm phổi mô kẽ do Pneumocystis jiroveci, phải điều trị cứu vớt G-CSF, truyền bạch cầu hạt và rút bỏ sonde tĩnh mạch trung ương. Chúng tôi cũng ghi nhận $n=1$ trường hợp $(2,6 \%)$ tử vong trong điêu trị, không do tái phát. Nguyên nhân là liệt ruột do Vincristine, tiến triển sốc nhiễm trùng.

\section{BÀN LUÂN}

Trong 38 mẫu bệnh nhân trong nhóm nghiên cứu, một tỉ lệ cao $(39,5 \%)$ có đột biến khác kèm theo. Các bất thường này đa dạng bao gồm một hoặc nhiều loại: chuyển đoạn khác, mất đoạn, lệch bội, đồng nhiễm sắc thể (isochromosome). Trong đột biến kèm theo thì lệch bội chiếm đa số (53,3\%); kết quả này tương đồng với một số nghiên cứu như của tác giả Fecile [4]. Nhưng có bất thường kèm theo cho thây không có sự khác biệt về sống còn. Chuyển đoạn $t(1 ; 19)$ không cân bằng chiếm ưu thế hơn một chút $(59,3 \%)$, tuy nhiên kết quả phân tích sống còn cũng cho thấy OS và $E F S$ của 2 nhóm chuyển đoạn cân bằng và không cân bằng là tương đương nhau. Kết quả này khác với kết quả của tác giả Uckun [7] là chuyển đoạn $t(1 ; 19)$ không cân bằng cho tiên lượng tốt hơn, nhưng tương đồng với nhiều nghiên cứu gần đây như của tác giả Fecile [4].

Về đặc điểm miễn dịch tế bào, có đến $89,5 \%$ các trường hợp không có kiểu hình LAIPs để theo dõi MRD sau điêu trị. Đặc điểm kháng nguyên quan trọng nhất để xếp vào kiểu LAIPs của $B C C L B$ trẻ em là kháng nguyên khác dòng vì có độ phổ biến cao, ít nhiễu và dễ lặp lại nhất. Kết quả nghiên cứu của chúng tôi phù hợp với nhiều nghiên cứu khác về sự hạn chế biểu hiện kháng nguyên khác dòng của đối tượng có tổ hợp gen E2A-PBX1 [2] [8]. Điều này chỉ ra công cụ sinh học phân tứ, cụ thể là kĩ thuật PCR định lượng (RQ-PCR) đóng vai trò chủ lực để đánh giá MRD. Đặc biệt là giá trị tiên lượng của MRD là rõ rệt nhất liên quan đến sống còn và tái phát.

Với phác đồ FRALLE 2000 được áp dụng tại bệnh viện Truyền máu - Huyết học Tp. HCM. Lui bểnh sau giai đoạn tấn công đạt $100 \%$, giống với nhiều nghiên cứu trên thế giới [5], [4]. Tỉ lệ sống toàn bộ và tỉ lệ sống không sự kiện 10 năm của mẫu nghiên cứu là 84,4 và $70,7 \%$. Tương đồng với các nghiên cứu lớn CCG [7], ở Argentina [4] và thấp hơn một chút so với nghiên cứu ở Trung Quốc [5]. Kết quả này cao hơn một chút với kết quả điều trị $B C C L B$ nói chung tại bệnh viện Truyền máu Huyết học của tác giả Huỳnh Thiện Ngôn $[1]$, cho thây $t(1 ; 19)$ không có giá trị tiên lượng xấu trong điêu trị
BCCLB với phác đồ FRALLE 2000. Theo kết quả nghiên cứu của chúng tôi, chỉ có giá trị MRD dương tính sau tấn công có giá trị tiên lượng có ý nghĩa nhất làm tăng nguy cơ tái phát bệnh ( $p$ $<0,01)$. Tî lệ tái phát chung là $21,1 \%$, với hầu hết là tái phát rất sớm trong 18 tháng sau chẩn đoán, thường nhất là ở giai đoạn duy trì, và một nửa là tái phát tuỷ lẫn thần kinh trung ương.

Biến chứng trong điều trị nổi bật là nhiễm trùng và tăng tranaminase gan, gặp ở hầu hết các giai đoạn của điều trị, nhưng chủ yếu là độc tính độ I-II. Đa phần là nhe, một số phải trì hoã̉n nhưng nhìn chung không làm ảnh hưởng điều trị toàn diện. Tuy nhiên có một trường hợp $(2,6 \%)$ có độc tính nghiêm trọng phải dừng điều trị là xơ tuỷ, không hồi phục huyết đồ và cũng $2,6 \%$ tử vong không do tái phát.

Nhược điểm nghiên cứu của chúng tôi là một khảo sát đơn trung tâm, hồi cứu, cỡ mẫu nhỏ nên việc phân tích còn nhiều hạn chế. Kỹ thuật để xác định MRD bằng Sinh học phân tử RQ-PCR mới được ứng dụng những năm gần nay nên trước đó đánh giá MRD chưa có độ nhạy phù hợp. Vì vậy, cần thiết có một nghiên cứu với cỡ mầu lớn hơn, đa trung tâm và đồng nhất về phương pháp đánh giá MRD để có mô hình tiên lượng chính xác hơn.

\section{KẾT LUÂNN}

Kết quả nghiên cứu cho thấy $t(1 ; 19)$ là yếu tố tiên lượng tốt với phác đồ điều trị FRALLE 2000. Tuy nhiên đối tượng này cũng bị ảnh hưởng bởi nhiều yếu tố khác trong đó rõ rệt nhất làm tăng nguy cơ tái phát bệnh là MRD sau tấn công. Với đặc điểm ít biểu hiện LAIPs, việc theo dõi bằng Flow cytometry rất hạn chế và do đó cần phát triển thêm dấu ấn khác để đánh giá. Trọng tâm để theo dõi MRD nên dựa trên kỹ thuật sinh học phân tử, cụ thể là PCR định lượng đóng vai trò rất quan trọng để tối ưu hoá mô hình tiên lượng và hiệu quả điều trị.

\section{TÀI LIÊU THAM KHẢO}

1. Huỳnh Thiện Ngôn, Huỳnh Thiên Hạnh Nguyển Quốc Vu Khanh (2019). "Đánh" giá hiệu quả điêu trị bệnh bạch cầu cấp dòng lympho ở trẻ em bằng phác đồ FRALLE 2000 trong 10 năm". Tạp chí Y Học TP. Hồ Chí Minh, 23, pp. tr.108 - 113.

2. Nguyễn Phương Liên (2012). "Ứng dụng kỹ thuật tế bào dòng chảy để đánh giá tôn lưu tể bào ác tính trong bệnh bạch cầu cấp". Luận văn tiến sĩ y hoc.

3. Võ Thị Thanh Trúc (2010). "Đánh giá hiệu quả điều tri bệnh bach câu cấp lympho ở trẻ em bằng phác đồ FRALLE 2000". Luận văn tốt nghiệp bác sĩ nội trú, Đại Học Y Dược TP. HCM. 
4. Felice M. S., Gallego M. S., Alonso C. N. (2011). "Prognostic impact of $\mathrm{t}(1 ; 19) /$ TCF3-PBX1 in childhood acute lymphoblastic leukemia in the context of Berlin-Frankfurt-Münster-based protocols". Leuk Lymphoma, 52 (7), pp. 1215-21.

5. Hu Yixin, He Hailong, Lu Jun (2016). "E2APBX1 exhibited a promising prognosis in pediatric acute lymphoblastic leukemia treated with the CCLG-ALL2008 protocol". OncoTargets and therapy, 9, pp. 7219-7225.

6. Hunger S. $P_{.}$, Lu $X .$, Devidas M. (2012). "Improved survival for children and adolescents with acute lymphoblastic leukemia between 1990 and 2005: a report from the children's oncology group". J Clin Oncol, 30 (14), pp. 1663-9.

7. Uckun F. M., Sensel M. G., Sather H. N. (1998). "Clinical significance of translocation $t(1 ; 19)$ in childhood acute lymphoblastic leukemia in the context of contemporary therapies: a report from the Children's Cancer Group". J Clin Oncol, 16 (2), pp. 527-35.

8. Kiyokawa Nobutaka, Iijima Kazutoshi, Tomita Osamu (2014). "Significance of CD66c expression in childhood acute lymphoblastic leukemia". Leukemia research, 38 (1), pp. 42-48.

\section{ĐẶC ĐIỂM CỦA BỆNH NHÂN ĐA U TỦY CÓ KHUẾCH ĐẠI 1q21 TẠI BỆNH VIỆN TRUYỀN MÁU HUYẾT HỌC}

\section{TÓM TẮT}

Mục tiêu: Mô tả đặc điểm lâm sàng, xét nghiệm lúc chẩn đoán và đặc điểm di truyền của bệnh nhân đa u tủy có khuếch đại NST 1q. Phương pháp nghiên cứu: Nghiên cứu hồi cứu cắt ngang mô tả hàng loạt ca. Đối tượng: 95 bệnh nhân đa u tủy mới chẩn đoán tại bệnh viện truyền máu huyết học thỏa tiêu chuẩn chọn mấu trong khoảng thời gian từ $1 / 2017$ đến 12/2020. Kết quả và bàn luận: Tỉ lệ bệnh nhân mang khuếch đại NST 1q là 29,5\% ( $\mathrm{n}=$ 28). Trong số các bất thường về lâm sàng, triệu chứng thiếu máu và đau nhức xương thường gặp nhất (> 70\%), ngoài ra còn có triệu chứng u tương bào, sụt cân, sốt, xuất huyết, không có sự khác biệt giữa 2 nhóm có và không có khuếch đai î̀. Tăng calci máu, tăng Beta-2-microglobulin, giai đoạn bệnh muộn, nhiều bất thường di truyền và bất thường thuộc nhóm nguy cơ cao là những đặc điểm khác biệt đáng kể giữa 2 nhóm nghiên cứu ( $\mathrm{p}<0.05)$. Kết luâan: Có sư khác biệt về các đặc điểm sinh học của nhóm bệnh nhân có khuếch đại NST $1 \mathrm{q}$, cho thấy nhóm BN nay thuộc nhóm nguy cơ cao.

Tư khóa: khuếch đại 1q21, đa u tủy, FISH, bất thường nhiễm sắc thể.

\section{SUMMARY \\ CHARACTERISTICS OF MULTIPLE MYELOMA PATIENTS WITH GAIN CHROMOSOME 1q AT BLOOD TRANSFUSION AND HEMATOLOGY HOSPITAL}

${ }^{1}$ Bênh viện Truyền máu Huyết hơc.

${ }^{2}$ Đại học Y Dược Thành phố Hồ Chí Minh.

${ }^{3}$ Đai hoc Y Khoa Pham Ngoc Thach, TP. Hồ Chí Minh. Chịu trách nhiệm chính: Phan Thị Xinh

Email: phanthixinh73@gmail.com

Ngày nhận bài: 1.6 .2021

Ngày phản biên khoa hoc: 2.8.2021

Ngày duyệt bài: 9.8.2021
Trần Thùy Anh ${ }^{1,2}$, Phạm Kim Thạnh ${ }^{2}$, Nguyễn Tấn Bỉnh ${ }^{3}$, Phan Thị Xinh ${ }^{1,2}$

Objectives: describe characteristics of clinical symptoms, laboratory values at diagnosis and genetic features in multiple myeloma patients with amplification of chromosome 1q. Methods: crosssectional descriptive studies are retrospective. Subjects: 95 patients newly diagnosed with multiple myeloma were included in this study at Blood transfusion hematology hospital from January 2017 to December 2020. Results: the frequency of patients with chromosome 1q amplification was $29,5 \%$ ( $n=$ 28). Among the clinical abnormalities, anemia and bone pain were the most common $(>70 \%)$. There were no difference between patients with and without 1q amplification in plasmacytoma, weight loss, fever and hemorrhage. However, hypercalcaemia, Beta-2microglobulin level, late stage of disease, multiple chromosomal abnormalities and high-risk genetic abnormalities were significant difference between 2 groups $(p<0.05)$. Conclusion: There are differences in the biological characteristics of the patients with chromosome 1q amplification, indicating that this group of patients belongs to the high-risk group.

Key words: 1q21 amplification, multiple myeloma, FISH, chromosome abnormalities.

\section{I. ĐẶT VẤN ĐỀ}

Đa u tủy là bệnh tân sinh ác tính của tương bào ở tủy xương và một số cơ quan khác, phổ biến thứ hai trong các bệnh lí ác tính huyết học và đặc trưng bởi tính không đồng nhất về mặt lâm sàng cũng như kết cục của bệnh nhân. Hiện nay, việc điều trị đa u tủy đã được cải thiện đáng kể, đó là nhờ sự ra đời của các thuốc mới như thuốc ức chế proteasome, thuốc điều hòa miễn dịch, kháng thể đơn dòng.... Tuy nhiên, đa u tủy là bệnh lí đáp ứng điều trị, nhưng sau đó sẽ tái phát, dù là ở nhóm bệnh nhân đạt được đáp ứng hoàn toàn (complete response - CR) ban đâu. Có nhiều yếu tố tiên lượng bệnh như nồng độ $\beta 2$ - 